Ministry of Education Iraqi Directorate of Education Baghdad Karkh III

First Conference Department of Preparation and Training Division of Research and Studies

وزارة التربية العراقية مديرية تريية بغداد الكرخ الثالثة المؤتمر الاول قسم الاعلاد والتلدريب شعبة البحوث واللدراسات

\title{
The Influence of the Graveyard School and the Transitional Poets on Romanticism
}

\author{
Wijdan Husain Ali \\ Directorate of Baghdad Education Karkh III, Ministry of Education, Baghdad, Iraq \\ Thesun048@gmail.com
}

\begin{abstract}
What was called "Graveyard School" is in fact, a number of Pre-Romantic English poets who concentrated on subjects of death and sorrow as well as temporality of life in their poems. It is clear that their themes were suggested in their group name. Tomb. Time and human life were presented in their poetry. They described sorrow and the loss of moral values using their imagination. The study sheds light on ' Graveyard School'; it is divided into two chapters and a conclusion. Chapter one gives a brief summary to this school, while chapter two focuses on the era's most creative and successful poets who brought the characteristics of this school in their poems. The conclusion sums the main findings that are given in this study.
\end{abstract}

\section{تأثير ملروسة المقابر والشعراء الانتقاليين على الرومانسية}

\author{
وجدان حسين علي \\ وزارة التربية، مديرية تربية بغداد الكرخ الثالثة، بغداد، العراق \\ Thesun048@gmail.com
}

المستخلص مدرسة المقابر هي مدرسة مستوحاة من خيال مجموعة من الشعراء خلال الحقبة الرومانسية في القرن السابع والثامن عشر، حيث تناولوا معاناة الانسان في ظل الحداثة والتقدم فكانت قصائدهم تعكس الخيبة والحزن والموت. قسمت هذه الدراسة الى مبحثين وخاتهم، تناول المبحث الاول مقدمه عن هذه المدرسة، بينما ركز المبحث الثاني عن أبرز شعراء هذه الحقبة. لخصت الخاتمة

$$
\text { النتائج الرئيسية التي قدمت في هذه الدراسة. }
$$

Ali, W. (2019). The Influence of the Graveyard School and the Transitional Poets on Romanticism. Journal Pon Science Research, 2(3), 481-484. doi.org/10.36371/port.2018.02.3.8 


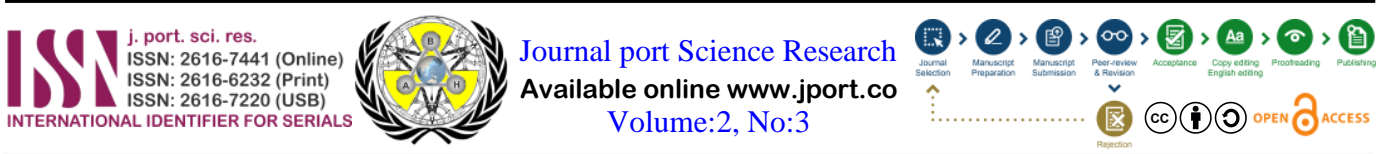

Introduction

Eighteenth century literature is saturated with a mixture of sadness and religious education. It was the cemetery poets known as the founders of the cemetery school [1] The Influence of the Graveyard School and The Transitional Poets on Romanticism When talking about the Romantic period it should be kept in mind that such a period has come from some preceding movements and tendencies that have given birth to this new page in the history of literature. Among such effects that have led to Romanticism are the graveyard school and transitional poets. [2] The term the graveyard school is given to the poets from the mid to the late eighteenth century. There is a group of poets that represents this school namely the Graveyard Poets. They are known as the founders of this type of school. What is most interesting about these poets is that they are characterized by their melancholy mood in composing poems. [3]

As it is suggested from the name. The Graveyard Poets often take as their theme's death in gloomy and cemeterial atmosphere ruins, tombs, churchyards, in addition to meditative moods on human suffering and on man's dusting. So apparently, the general atmosphere in which these oats create their works tends to be in isolation. This is probably the first step in the way to the new movement, Romanticism, for the romantic poets are also known of their isolation. [4] In addition to this, the themes or subjects that they talk about may be seen as the cornerstone of the Romantic Poets; the graveyard poets often take these themes that have connection with nature or even matters that has a relation to Man's state whether in life or after death. Presenting gloomy atmospheres is based on tight ground. [5] Indeed, the English mind is proverbially melancholy and citations from the author of the earliest periods of the Anglo- Saxon literature would reveal states of mind as gloomy and meditative [6] as those revealed in the ' Grave' and the 'Elegy'. For instance, Thomas Gray's poem, [7] Elegy Written in a Country Churchyard (1751) [8] presents a sight of rural churchyard. It is not singularly patrol poem or an elegy in too sad a mood. However, it represents a combined style of both: his reflection on the dead, who are real beings or fancy images, and the description of the country life as a background.3Thus, Gray attempts to praise the peasants utilizing his melancholy sympathy. [9] There is the idea of noble savage of the return or nature which is purely Romantic. Man would be noble when he has no over ambition, envy, and pride and so on. In the same way, Man is savage because he is not educated, but brought up in nature.

"Let not Ambition mock their useful toil,

Their homely joys, and destiny obscure;

Nor Grandeur hear with a disdainful smile

The short and simple annals of the poor."

(line 29-32)

This poem, as a whole, sets a comparison between the dead and the alive. This may work symbolically for those who are dead in life; they are dead morally. He is trying to warn people to return to their ethics. [11] One of the most important turning points of this poem towards Romanticism lies in the lines as he is talking about himself as a poet:

\section{"Here rests his head upon the lap of Earth}

A youth to Fortune and to Fame unknown."

(line 117-118)

The return to nature the lap of Earth is purely Romantic; the earth is represented as the mother of the poet. [11] James Thomson exploits the same presentation and harmony of nature in his poem The Seasons which represents another transitional point towards Romanticism. Most notably, Thomason uses georgic poetry in his poem in which draws inspiration from the noble tabors of the farmer. [12]

علي، وجدان حسين. (2019). تأثير مدرسة المقابر والشعراء الانتقاليين على الرومانسية. Journal Port Science، doi.org/10.36371/port.2018.02.3.8 484-481 ، (3) ، Research 
Those people prefigure one of the most obvious features of the Romanticism poets which is solitude as a trainer of morale and an escape from the vanities of the world. [13] Thus, solitude constitutes the source of inspiration for them. As a preliminary stage for Romanticism.

It is believed that melancholy subjects were by no means unfamiliar to the writers, both of poetry and prose, of the seventeenth century, The love of gloomy, imagery of the grave, the gasp of dying, the brevity of life, the vanity of wealth, the restorative virtues of solitude, have all been treated by poets and prose writers before the dawn of the century that saw the production of the (Elegy), (The Grave) and (The Night Pieace of Death). [14] Concerning Goldsmith's poem (The Deserted Village), it foretells a deserted world. (There will come a time when this temporary solitude may be made continually, and the city itself, like its inhabitants, fades away, and leaves a desert in its room). [15]

Thus, the thematic treatment is pre-Romantic in this poem a deserted village means a village that has lacked something not necessarily people, that is to say they lack values, humanity and other concepts that this poet has witnessed earlier than other people. [16] Psychologically speaking, such continuous insistence on somber and sad atmosphere has helps to plant a new movement inheriting most of the features of this preceding wave of poetry. [17]

\section{Conclusion}

The English graveyard poets regarded death as a transitional phase and a bridge to transfer the individuals from the postmodern life to the everlasting life. By using their imaginations; they created gloomy and dark atmospheres in their poems. Their philosophy concerned with sorrow, pain and death as the most important characteristic of this school. Death is the best way to achieve peace and freedom. They believe that life is rejected; they prefer the other world, since they do not know their real life. The graveyard poets preferred the world of death as the spiritual relief. The metaphors they used in their poems as isolating factors: are darkens, the inability to recognize between day and night, light and dark, happiness and sorrow. They struggle with strong power called life; they live in an alien world. This school is a state of confusion that results from conflicting pressures and produces anxiety in the life of individuals. Their poets wrote poems which seem focused on human mortality, and likewise they have often led unfortunate lives, and were relatively dark people by personality. Their poetry colored with images of death, including a gloomy atmosphere of a graveyard, tombs, and funerals. The tone of their poetry, solemnity, is supported by focusing attention on certain words like pain, sorrow and death.

\section{References}

[1] Graveyard Poets. Vade Mecum: A GRE for Literature Study Tool. Duke. Archived from the original on 2 October 2013. Retrieved 8 December 2012.

[2] Winstanley, L., \& Symons, A. (1910). The Romantic Movement in English Poetry. The Modern Language Review, 5(2), 234. https:// doi.org/10.2307/3713350

[3] Clark, C. D. (1930). The Funeral Elegy, and the Rise of English Romanticism. John W. Draper. American Journal of Sociology, 35(4), 672-673. https:/ / doi.org/10.1086/215156

[4] AKHAVAN, O. (2015). Poetic Reflections in a Cemetery: A Comparative Study of English and Persian Graveyard School of Poetry. Cumhuriyet University Faculty of Science, Science Journal (CSJ), 36(3) Special Issue. https: / / dergipark.org.tr/ download/article-file/ 713840

Ali, W. (2019). The Influence of the Graveyard School and the Transitional Poets on Romanticism. Journal Pon Science Research, 2(3), 481-484. doi.org/10.36371/port.2018.02.3.8 
j. port. sci. res.
ISSN: $2616-7441$

[5] Elliott, B., \& Curl, J. S. (2001). The Victorian Celebration of Death. Garden History, 29(2), 229. https:// doi.org/10.2307/1587391

[6] Orchard, A. (2011). Beowulf. In the Cambridge Companion to Old English Literature (pp. 137-158). Cambridge University Press. https: / doi.org/10.1017/CCO9781139042987.014

[7] Kaur, K. (2018). Totentanz and Graveyard Poetry: about the Baltic German Reception of English Graveyard Poetry / Totentanz ja graveyard poetry: inglise kalmuluule baltisaksa retseptsioonist. Methis. Studia Humaniora Estonica, 17(21/22). https: / / doi.org/10.7592/methis.v17i21/22.14583

[8] Gray, T. (2018). Poet's Pen: Elegy Written in a Country Churchyard. Methodist DeBakey Cardiovascular Journal, 14(3), 239-240. https:/ / doi.org/10.14797/mdcj-14-3-239

[9] King, J., \& Cornford, S. (1991). Edward Young: "Night Thoughts." The Modern Language Review, 86(1), 173. https:// doi.org/10.2307/3732117

[10] Harold Monro: poet of the New Age. (2001). Choice Reviews Online, 39(03), 39-1398-39-1398. https: / / doi.org/10.5860/ choice.39-1398

[11] McRAE, J. (1998). The language of poetry. London: Routledge. https: / / www.questia.com/read/103834466/ the-language-of-poetry

[12] Fairer, D. (2008). James Thomson, The Seasons. In A Companion to Literature from Milton to Blake (pp. 284-290). Blackwell Publishing Ltd. https:/ / doi.org/10.1002/9781405165327.ch27

[13] Phelpstead, C. (2019). Chris Jones. Fossil Poetry: Anglo-Saxon and Linguistic Nativism in Nineteenth-Century Poetry. The Review of English Studies. https: / / doi.org/10.1093/res/hgz076

[14] Kaur, K. (2018). Totentanz and Graveyard Poetry: about the Baltic German Reception of English Graveyard Poetry / Totentanz ja graveyard poetry: inglise kalmuluule baltisaksa retseptsioonist. Methis. Studia Humaniora Estonica, 17(21/22). https: / / doi.org/10.7592/ methis.v17i21/22.14583

[15] Bell, A. (2015). The Irish poet and the natural world: an anthology of verse in English from the Tudors to the Romantics. Green Letters, 19(1), 107-109. https: / / doi.org/10.1080/14688417.2014.989730

[16] Chaden, C. (2007). Oliver Goldsmith, The Deserted Village, and George Crabbe, The Village. In $A$ Companion to Eighteenth-Century Poetry(pp. 303-315). John Wiley and Sons. https:// doi.org/10.1002/9780470996638.ch23

[17] Goldsmith, O. (2019). The Deserted Village, a Poem. The Deserted Village, a Poem. Columbia University Press. https: / doi.org/10.7312/gold93300 